\title{
An Empirical Testing of a House Pricing Model in the Indian Market
}

\author{
Najmul HODA ${ }^{1}$, Syed Ashraf JAFRI ${ }^{2}$, Naim AHMAD ${ }^{3}$, Syed Mannawar HUSSAIN ${ }^{4}$ \\ Received: June 02, 2020 Revised: June 28, 2020 Accepted: July 09, 2020
}

\begin{abstract}
The main aim of the study is to test a house pricing model by combining hedonic and asset-based pricing models. An understanding of the relationship between house pricing and its return (the rental income) helps to establish houses as a significant asset class. The model tested the relationship between house pricing (dependent variable) and the house attributes (independent variables) derived from Freeman's framework of housing attributes. This study uses a large data-set of 1,899 sample of new, high-end houses purchased between 2016 and 2019 collected from the national capital region of India (Delhi-NCR). The algorithm was built in R-Script, and stepwise multiple linear regression was used to analyze the model. The analysis of the model proves that the three significant variables, namely, carpet area, pay-off, and annual maintenance charges explain the price function. Further, the model is statistically fit. The major contribution of the study is to understand the key factors and their influence on the house pricing. The model will be helpful in risk assessment in the housing investment and enhance the chances of investment. Policy-makers can use information about the underlying valuation drivers of the house prices to stabilize the market and also in framing the tax policies.
\end{abstract}

Keywords: House Pricing Model, Asset Pricing Model, National Capital Region, R-script, Step-wise Multiple Linear Aggression

JEL Classification Code: G1, C4, M2, R3

\section{Introduction}

Houses have gained the status of a valuable asset class in both the developed and developing countries. Housing is reported to provide an excellent risk-return trade-off and is a good alternative to stock and bond portfolios. Relative to the stocks and bonds investment, direct housing investment

${ }^{1}$ First Author and Corresponding Author. Assistant Professor, Department of Business Administration, College of Business, Umm Al-Qura University, Kingdom of Saudi Arabia [Postal Address: Al-Abidiyah, Makkah, 21955, Kingdom of Saudi Arabia] Email:nnhoda@uqu.edu.sa

2Statistician, Statisticka Consulting Group, India. Email: ashrafjafri66@gmail.com

${ }^{3}$ Lecturer, Department of Information Systems, College of Computer Science, King Khalid University, Kingdom of Saudi Arabia. Email: nagqadir@kku.edu.sa

${ }^{4}$ Senior Engineer - Electrical, Mosanada Facilities Management Services, Doha, Qatar. Email: mannawar.hussain@mosanada.qa

(c) Copyright: The Author(s)

This is an Open Access article distributed under the terms of the Creative Commons Attribution Non-Commercial License (http://Creativecommons.org/licenses/by-nc/4.0/) which permits unrestricted noncommercial use, distribution, and reproduction in any medium, provided the original work is properly cited. provides advantages in the form of rental income as well as a capital gain (Baek \& Lee, 2018). It also offers an inflation hedge in the long run.

Developing appropriate house pricing or valuation method is important for several reasons. First, houses as an asset class face unique challenges in their valuation because of their relative differences compared to other assets like equity, commodities, bonds, etc. Second, house prices are one of the indicators of the macroeconomic situation, thereby necessitating the use of an appropriate and effective method of house pricing or valuation (Calomiris, Longhofer, \& Miles, 2009; Wang \& Kim, 2014). Another important reason is the utilization of house pricing by various sectors like banking, real estate (market correction) and government (cost-of-living index).

Indian real-estate market is developing as an attractive investment opportunity for local and foreign investors. In 2019 , the housing sector reported a sale of 0.26 million houses in seven major cities (IBEF, 2020). Further, the real-estate sector in India is expected to reach USD1 trillion by the year 2030. As per a report, the main reasons for the rapid growth of the real-estate sector, including housing, in India are, "rising purchasing power, continuously rising population, 
increasing investments in socio-economic infrastructures, rapid urbanization and migration of people from rural to urban areas" (Research and Markets, 2015). There are very few econometric studies on urban house pricing in India. This research tries to fill this gap by empirically testing a model of house pricing in Delhi-NCR (National Capital Region).

The primary aim of the study is to develop a model for house prices, including investment factors. It tries to refine the hedonic pricing model by considering the variables used in the asset pricing model. The model is evaluated by regression analysis and confirmed by the application of robustness checks. The rest of the paper is structured as follows. Section 2 discusses the theoretical background of the research. Section 3 describes the research methodology. Section 4 illustrates the house pricing regression models. The results are discussed in Section 5. Section 6 concludes the research findings.

\section{Literature Review}

This section describes the existing models of house pricing, variables affecting the house pricing, and a review of the past studies.

\subsection{Models of House Pricing}

House pricing methods or models have been classified into "Traditional" and "Advanced" Kuşan, Aytekin and Özdemir (2010) and Pagourtzi et al. (2003). The traditional models apply comparison methods or regression. Some common methods in the traditional models are, "comparable method, investment/income method, profit method, development/residual method, contractor method, multiple regression method and stepwise regression method". Advanced models consider the behavioral aspects of the market players. These models include, "artificial neural networks (ANN), hedonic pricing method, spatial analysis method, fuzzy logic (FL), and Autoregressive Moving Average (ARMA)" (Kuşan et al., 2010). Nguyen (2016) has listed more methods, namely, sales or rent comparison model, capital asset pricing model, the income approach, and the cost (of construction) approach.

\subsection{Hedonic Pricing Model}

The literature review shows that the hedonic pricing model has been consistently used for predicting/valuing house prices (Randeniya, Ranasinghe, \& Amarawickrama, 2017; Lisi, 2019; Sunak \& Madlener, 2017; Pace \& Zhu, 2017; Kuşan, Aytekin, \& Özdemir, 2010; Debrezion, Pels, \& Rietveld, 2007; Diao \& Ferreira, 2010; Li et al., 2015; Sunding \& Swoboda, 2010). S. Rosen is believed to be the earliest proponent of the hedonic model (Liu, 2013). This model views houses as a product with bundles of attributes (Lisi, 2019; Liu, 2013; Harrison \& Rubinfeld, 1978). In the conventional product pricing, price depends on demand whereas in case of houses the price is determined by features (Oladunni \& Sharma, 2017). Liu (2013) also mentions that the main reason for the popularity of the hedonic method has been attributed to the heterogeneity of the product (houses), and the unpredictable nature of its transaction. The hedonic model has received criticisms too (Abidoye \& Chan, 2017, 2018). Oladunni, Sharma and Tiwang (2017) point out the issues in the open-ended nature of the house attributes. Fan, Ong and Koh (2006) elaborate on the weaknesses further by focusing on the basic model assumptions.

\subsection{Asset-based Pricing Model}

Since houses have been positioned as an asset, the capital asset pricing model or asset-based pricing model has gained prominence in the pricing and valuation of houses. The asset pricing model applies the concepts of risk, return, opportunity cost and tests the price in terms of return on investment (ROI) (Phuoc, 2018). When translated into the concept of ROI, it provides a better tool for the stakeholders for dealing in houses. The asset pricing model is being applied more also because the simple log or power utility models could not account for "basic features of asset pricing data and time-series behavior of asset returns" (Hansen \& Cochrane, 1992). Palmquist (1980) applied asset pricing model to house market in their study based in the United Kingdom. They justified that the use of this model gives a more elaborate view of the influence of factors on house pricing. The asset pricing model applies a similar concept to house pricing as in the equity market wherein instead of the Price-Earnings ratio, House Price to Net Rentals is applied in the housing market (Campbell \& Cochrane, 2000). Gelain and Lansing (2014) have highlighted that the asset pricing model is better equipped to predict the volatility and influencing factors related to housing pricing.

\subsection{Past Studies}

The literature on house pricing reveals many factors that have been employed as a function of house pricing. Freeman (1979) proposed one of the most popular frameworks for considering the variables of house pricing. He suggested there are three key attributes in the housing market, namely, structural attribute (S) such as the size of a building; accessibility or locational attribute (L) such as the distance to central business districts; and neighborhood (N) attribute such as the quality of the surroundings. These or similar categories were used in other studies (Dubin, 1998; Nguyen \& Do, 2020; Oladunni et al., 2017; Selim, 
2008). Environmental factors have also been added as an attribute in house pricing in a recent study (Hussain, Abbas, Wei, \& Nurunnabi, 2019). Within these broad categories, some researchers have focused on some specific attributes like air pollution (Harrison \& Rubinfeld, 1978); wind farm (Sunak \& Madlener, 2017); agriculture (Ready \& Abdalla, 2005; Yoo \& Ready, 2016); house interiors (Sirmans, Macpherson, \& Zietz, 2005); schooling (Yuan, Wei, \& $\mathrm{Wu}, 2020$ ); open space (Zainora Asmawi, Mohit, Noor, Abdullah, \& Paiman, 2018). Kuşan et al. (2010) modified the traditional categories and named them "House factors; Environmental factors; Transportation factors". Stadelmann (2010) considered thirty-one house pricing variables for their study based in Zurich. They discovered that locationspecific variables are the most significant. Kuşan et al. (2010) applied the Fuzzy Logic system, to develop a model for predicting house prices. They considered the variables such as public transport, educational building, that fall under the category of Accessibility or Location Attribute. Some studies also considered macro-economic variables (Kim \& Park, 2005; Kok, Ismail, \& Lee, 2018; Nguyen, Bui, \& Nguyen, 2019).

\section{Research Methods and Materials}

\subsection{Mathematical Functional Form}

In this study, the equation has been modeled as a hedonic housing regression borrowing the features of an asset-pricing model. House prices can be expressed as a function of the three factors present in Freeman's framework (Randeniya et al., 2017).

$P=f(S, N, L)$

Where, $\mathrm{S}=$ Structural attribute, $\mathrm{N}=$ Neighborhood attribute, and $\mathrm{L}=$ Locational attribute

The most important aspect of the asset-based pricing model is that, if the rent-to-price ratio exceeds the user-cost rate, renting becomes less attractive than ownership. When the rents equal the costs of owning, a state of equilibrium is reached. This rent-to-price relationship fits well in markets where rental regulation is absent or limited $(\mathrm{Tu}$, de Haan, $\&$ Boelhouwer, 2017). We have based our pricing models on multiple regressions, where the prices of an individual property is a response (dependent) variable, and their associated characteristics, are explanatory (independent) variables. Mathematically we formulate the model as:

$\mathrm{Y}=\alpha+\mathrm{X}_{1} \beta_{1}+\mathrm{X}_{2} \beta_{2}+\ldots+\mathrm{X}_{\mathrm{n}} \beta_{\mathrm{n}}+\varepsilon$

Where,

$\mathrm{Y}=$ Response Variable (Price)
$\mathrm{X}_{\mathrm{i}}=$ Explanatory Variables affecting the price

$\alpha=$ Intercept

$\varepsilon=$ Error term

$\beta_{1}, \beta_{2}, \ldots \beta_{\mathrm{n}}$ are the regression coefficient associated with the respective explanatory variables $X_{1}, X_{2}, \ldots X_{n}$.

\subsection{Data and Method}

The research design of this study is a non-experimental and explanatory design that used a multiple regression analysis to test the relationship between price and rent. The data collection process involved contacting the real estate dealers in the Delhi-NCR region. The details and contact addresses of the dealers were collected from yellow pages and various online platforms. A total data set of 2,249 house buyers was received from the various dealers. The data cleaning process included removal of missing values and outliers, rounding up of numeric values to two-digits, selecting ready-to-move high-end properties (price $>$ INR 10 million), recently built (2016-2019) with sufficient social infrastructure. We applied these parameters to ensure that the property may qualify better as an investment asset. Because of the data cleaning process, the final sample of 1,899 (response rate $=84.4 \%$ ) was found fit for further statistical analysis. The occupation of house buyers was found to be business $(25.9 \%)$, private service $(25.2 \%)$, government service $(24.8 \%)$ and foreign employment (24\%)

The master dataset was then imported in R environment and transformed into a data frame. First, the dataset is listed and checked if the assumption of independence of the variable has been met by carefully examining that there is only one data point per subject (observation). Further, crosstabulations were used to validate the data through frequency analysis. Univariate normality, assumption and outliers are checked, and to do this, the box-and-whisper plots were plotted.

\subsection{Study Variables}

The proposed house-pricing model comprises of two different types of variables - the response variable (dependent) and the explanatory variables (independent). The response variable is the price. The Freeman framework was considered for selecting the explanatory variables (Freeman, 1979). As per the framework, the variables affecting house pricing may be categorized into three main factors, namely, the structural attribute; accessibility or locational attribute; and neighborhood attribute. The details of the response and explanatory variables are presented in Tables 1 and 2. Table 1 presents the summary of qualitative explanatory variables, which are categorical. The quantitative explanatory variables, which are discrete or continuous are presented separately in Table 2. 
Table 1: Qualitative explanatory variables

\begin{tabular}{|c|c|c|c|c|}
\hline Name of the variable & Description of the variable & Categories & Count (N) & Frequency (\%) \\
\hline \multirow{4}{*}{ Location } & \multirow{4}{*}{$\begin{array}{l}\text { The location where the } \\
\text { property purchased }\end{array}$} & Gurgaon & 516 & $27.17 \%$ \\
\hline & & New Delhi & 451 & $23.75 \%$ \\
\hline & & Noida & 460 & $24.22 \%$ \\
\hline & & Faridabad & 472 & $24.86 \%$ \\
\hline \multirow{4}{*}{ Type of Properties } & \multirow{4}{*}{$\begin{array}{l}\text { The property type concerning } \\
\text { the number of bedrooms (BHK } \\
\text { - bedroom, hall and kitchen) }\end{array}$} & One BHK & 470 & $24.75 \%$ \\
\hline & & Two BHK & 490 & $25.80 \%$ \\
\hline & & Three BHK & 430 & $22.64 \%$ \\
\hline & & Four BHK & 509 & $26.80 \%$ \\
\hline \multirow{4}{*}{ Type of Housing } & \multirow{4}{*}{ Type of property purchased } & Villa & 468 & $24.64 \%$ \\
\hline & & Apartment & 491 & $25.86 \%$ \\
\hline & & $\begin{array}{l}\text { Flats In Big Housing } \\
\text { Societies }\end{array}$ & 434 & $22.85 \%$ \\
\hline & & DDA Apartments & 506 & $26.65 \%$ \\
\hline \multirow{4}{*}{ Year of Purchase } & \multirow{4}{*}{$\begin{array}{l}\text { Year of purchase of property } \\
\text { by the end-user }\end{array}$} & 2016 & 465 & $24.49 \%$ \\
\hline & & 2017 & 492 & $25.91 \%$ \\
\hline & & 2018 & 478 & $25.17 \%$ \\
\hline & & 2019 & 464 & $24.43 \%$ \\
\hline \multirow{4}{*}{ Leasing Period } & \multirow{4}{*}{$\begin{array}{l}\text { Expected leasing period (in } \\
\text { years) }\end{array}$} & $0-5$ & 450 & $23.70 \%$ \\
\hline & & $6-10$ & 454 & $23.91 \%$ \\
\hline & & $11-15$ & 514 & $27.07 \%$ \\
\hline & & 15 And Above & 481 & $25.33 \%$ \\
\hline \multirow[b]{2}{*}{ Payment method } & \multirow{2}{*}{$\begin{array}{l}\text { The method by which property } \\
\text { is purchased (cash payment/ } \\
\text { bank loan) }\end{array}$} & Cash Purchased & 1891 & $99.58 \%$ \\
\hline & & Bank Loan & 8 & $0.42 \%$ \\
\hline \multirow{2}{*}{ Social Infra-Structure } & \multirow{2}{*}{$\begin{array}{l}\text { The available social } \\
\text { infrastructure in the vicinity }\end{array}$} & Yes (Sufficient) & 1462 & $76.99 \%$ \\
\hline & & No (Not Sufficient) & 437 & $23.01 \%$ \\
\hline
\end{tabular}

Table 2: Descriptive Statistics of Quantitative Explanatory Variables

\begin{tabular}{|l|l|c|c|}
\hline \multicolumn{1}{|c|}{ Name of the variable } & \multicolumn{1}{|c|}{ Description of the variable } & Mean \pm SD & Max, Min \\
\hline $\begin{array}{l}\text { Price (Indicative in million Indian } \\
\text { rupees) }\end{array}$ & $\begin{array}{l}\text { Indicative selling price (in million } \\
\text { Indian Rupees) }\end{array}$ & $1.89 \pm 0.68$ & $1.00,1.00$ \\
\hline Size (Carpet area in the square foot) & The total carpet area in square foot & $7674.53 \pm 3511.53$ & 19436,649 \\
\hline $\begin{array}{l}\text { Payoff (Expected annual rental } \\
\text { income in INR hundred thousand) }\end{array}$ & $\begin{array}{l}\text { The expected payoff in the form of } \\
\text { monthly rental plus security deposit }\end{array}$ & $7.44 \pm 0.97$ & $11.00,4.00$ \\
\hline $\begin{array}{l}\text { Annual maintenance amount (in INR } \\
\text { hundred thousand) }\end{array}$ & $\begin{array}{l}\text { Amount of money spent on annual } \\
\text { maintenance inclusive of annual } \\
\text { property tax }\end{array}$ & $1.60541 \pm 0.599$ & $3.3,0.38$ \\
\hline $\begin{array}{l}\text { Rental Increment (percentage of } \\
\text { increase expected annually) }\end{array}$ & $\begin{array}{l}\text { Increase in the rental amount } \\
\text { of property considering the } \\
\text { appreciation of property each year }\end{array}$ & $4.90 \pm 1.50$ & $7.50,2.25$ \\
\hline
\end{tabular}




\section{Results and Discussion}

Stepwise multiple linear regression modeling applied to test the pricing model stated in section 2 . The rationale behind applying the multiple regression models is that it helps in testing several explanatory variables simultaneously. A stepwise regression method is a combination of a forward selection and backward elimination. The major advantage of the stepwise selection is that it can select a subset of explanatory variables by using statistical criteria (Prost, Makowski, \& Jeuffroy, 2008). We have deleted the outliers as the OLS (ordinary least square) estimators are too sensitive to outliers present in the data.

\subsection{Regression Results}

We started with the first hedonic pricing model, wherein we have considered all the eleven explanatory variables. The variables are scaled as Z-score, to normalize its units, range and magnitudes. Three explanatory variables carpet area (size of the property); payoff (rental income); and the annual maintenance charges, were found to be statistically significant. This finding supports the postulated price function. The regression results are presented in Table 3. Step-wise regression method applied to test the second hedonic model. This statistical procedure helps identify the best statistical model which neither under fits nor over fits based on AIC (Akaike's Information Criterion). AIC is a powerful and popular model selection statistical tool that is based on the maximum likelihood estimator (Pan, 2001) Again, it helps identify significant explanatory variables contributing to the model. The result confirms that the statistically significant variables identified in model 1 are significant along with the intercept. Finally, we test the house-pricing model with the three statistically significant variables. This model not only confirms the price function but established the statistical model fit.

A summary of the estimates of the three models on different statistical parameters is presented in Table 3 .
It may be noted that the models are similar to the various parameters. The variance information factor (VIF) tests the multicollinearity in the models and also the relative strength of the models. The results show that there is no multicollinearity in any of the models. Further, model 3 has the smallest VIF value showing that it best explains the model relationship.

The correlation plot presented in Figure1 helps in understanding that the explanatory variables of price function are not linearly correlated. Also, the absence of heteroscedasticity was tested by applying Breusch-Pagan test and we find that the p-value is $9.219 \mathrm{e}-05(<0.05)$ confirming the absence of heteroscedasticity.

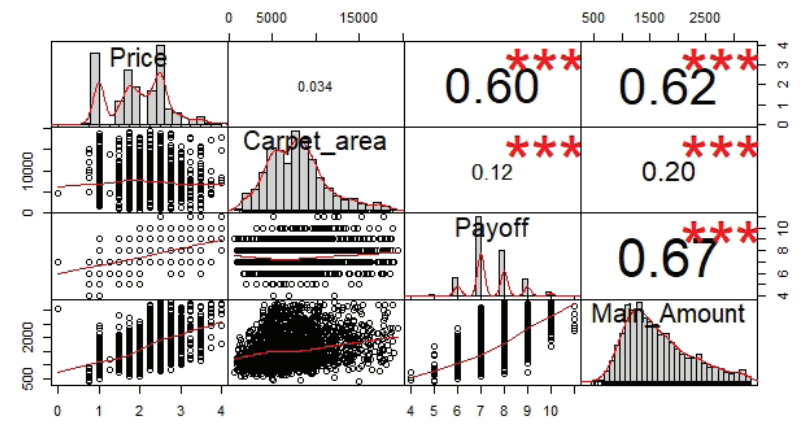

Figure 1: Correlation plots

As per statistical conditions, all linear models need to satisfy some strong assumptions concerning the data structure. These are: (i) multivariate normality; (ii) no multi-collinearity; (iii) linearity and; (iv) homoscedasticity. Violating these assumptions may undermine the validity of the regression models. The three regression models meet the above-stated assumptions, as evident by the regression plots. The diagnostic plots are illustrated in Figure 2. Therefore, it is safe to assume that the obtained model is relatively sound and trustworthy on the defined statistical criterion.

Table 3: Evaluation of the models

\begin{tabular}{|c|c|c|c|c|c|}
\hline \multicolumn{2}{|c|}{ Parameters } & Model 1 & Model 2 & Model 3 & Criterion \\
\hline \multicolumn{2}{|l|}{ RSE } & 0.5062 & 0.5057 & 0.5059 & Smaller the better. \\
\hline \multicolumn{2}{|l|}{$\mathrm{R}^{2}$} & 0.4502 & 0.451 & 0.4495 & Higher the better. \\
\hline \multicolumn{2}{|c|}{$R^{2}$ coefficients (adjusted). } & 0.449 & 0.4478 & 0.4486 & Higher the better. \\
\hline \multicolumn{2}{|c|}{$p$-value of ANOVA } & $<2.2 \mathrm{e}-16$ & $<2.2 \mathrm{e}-16$ & $<2.2 \mathrm{e}-16$ & Smaller the better. \\
\hline \multirow{3}{*}{$\begin{array}{l}\text { Variance } \\
\text { Information } \\
\text { Factor(VIF) }\end{array}$} & Payoff & 1.842388 & 1.831725 & 1.831724 & Smaller the better. \\
\hline & Carpet & 1.043157 & 1.040974 & 1.040809 & \multirow{2}{*}{$\begin{array}{l}\text { All VIFs }<4 \text {, hence } \\
\text { no multicollinearity }\end{array}$} \\
\hline & Maintenance Amount & 1.890107 & 1.883188 & 1.879999 & \\
\hline
\end{tabular}




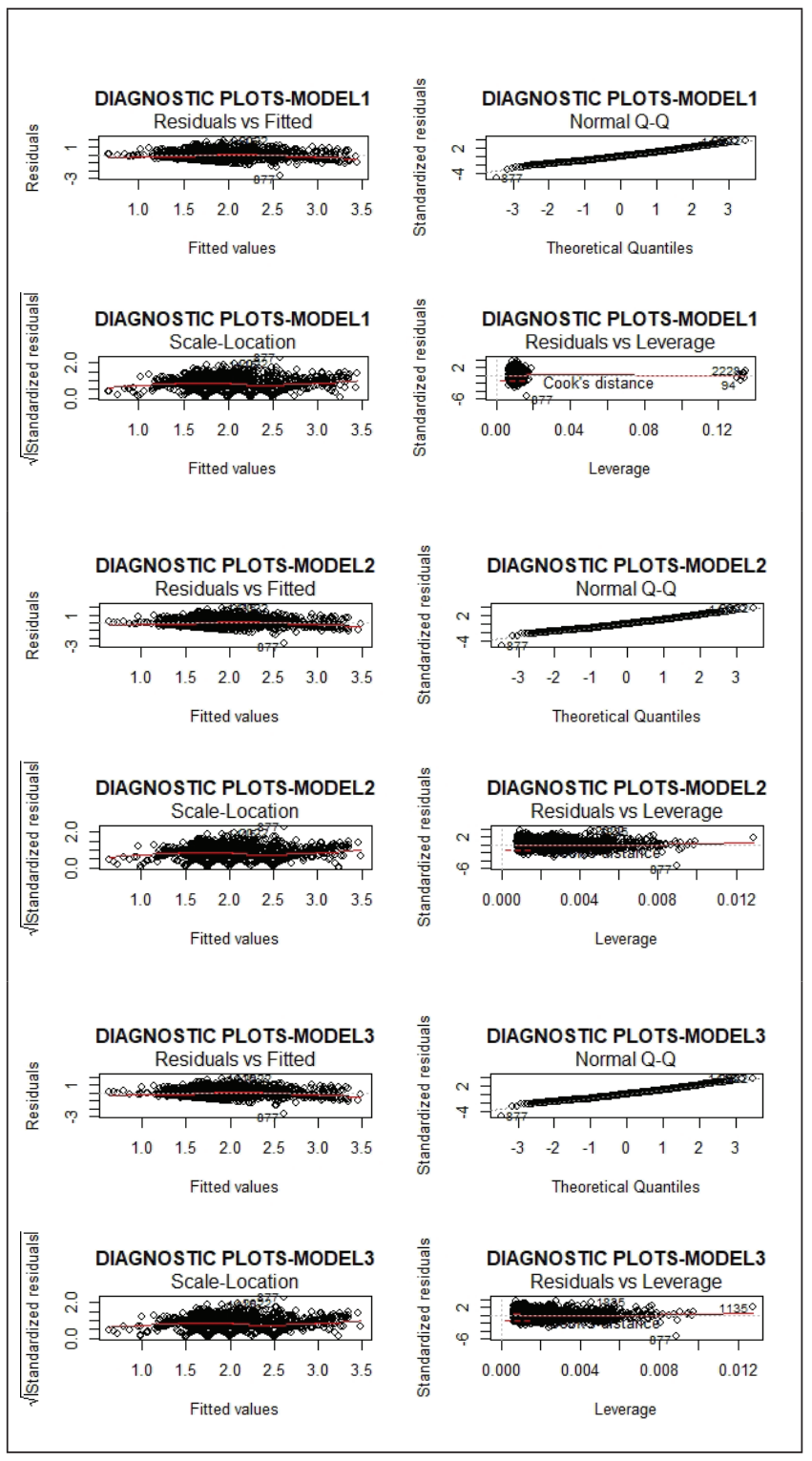

Figure 2: Diagnostic Plot Analysis for all Models

\section{Conclusions}

It is imperative to have a proper understanding of the relationship between housing prices and rents to reflect an asset price. This study aimed to understand house pricing, considering it as an asset, with a focus on the Indian real estate market. An understanding of the relationship between housing price and its earning in terms of rental income is significant for ascertaining the investment worthiness of houses. An important contribution of this study is to combine the assetpricing model with the hedonic model. The model, when checked against various statistical parameters, confirms that it conforms to the standards. The R-square $(>0.44)$, adjusted R-square $(>0.44)$ and residual standard error $(\leq 0.51)$ is taken into account for model fit. A minimum benchmark of R-Squared is 0.45 is taken for the model to be accepted. In a price-to-rent framework, credit standards for first-time home-buyers significantly affect house prices, in line with theory (Ortalo-Magné \& Sven, 2006).

This study offers insight for modeling of housing prices and rental estimates where market sentiments, laws of economic geography and urban economics play a more dominant role. The most important and complex task of housing pricing modeling is the selection of variables. The application of stepwise method has helped in selection of important features that may be utilized for the development of housing price index. The pricing model arrived at, helps to understand the dynamics of housing prices and potential risks of the economic law of return (investment) for strategic business planners of the housing industry. Also, pricing can be used for making marketing mix models. Future research on the housing models will enable to plan the housing rental index, the calculation of taxes and the development of social infrastructure will help generate more multiple effects on the urban economies.

The main limitation of the study is that housing price model works only on the assumption of market equilibrium, which is not true. The second factor that limits the effectiveness of such a model is the difficulty in measurement of some attributes such as social infrastructure, construction quality, etc. This study could not include external factors such as taxes and interest rates that may be a limitation on the generalizability of the model.

\section{References}

Abidoye, R. B., \& Chan, A. P. C. (2017). Critical review of hedonic pricing model application in property price appraisal: A case of Nigeria. International Journal of Sustainable Built Environment, 6, 250-259. https://doi.org/10.1016/j.ijsbe.2017.02.007

Abidoye, R. B., \& Chan, A. P. C. (2018). Improving property valuation accuracy: A comparison of hedonic pricing model and artificial neural network. Pacific Rim Property Research Journal, 24(1), 71-83. https://doi.org/10.1080/14445921.2018 .1436306

Baek, U., \& Lee, S. K. (2018). Searching for comparative value in small and medium-sized alternative accommodation: A synthesis approach. Journal of Asian Finance, Economics and Business, 5(2), 139-149. https://doi.org/10.13106/jafeb.2018. vol5.no2.139

Calomiris, C. W., Longhofer, S. D., \& Miles, W. (2009). The (Mythical?) Housing Wealth Effect. NBER Working paper 1575. https://doi.org/10.2139/ssrn. 1424106 
Campbell, J. Y., \& Cochrane, J. H. (2000). Explaining the poor performance of consumption-based asset pricing models. Journal of Finance, 55(6), 2863-2878. https://doi. org/10.1111/0022-1082.00310

Debrezion, G., Pels, E., \& Rietveld, P. (2007). The impact of railway stations on residential and commercial property value: A metaanalysis. Journal of Real Estate Finance and Economics, 35(2), 161-180. https://doi.org/10.1007/s11146-007-9032-z

Diao, M., \& Ferreira, J. (2010). Residential property values and the built environment: Empirical study in the Boston, Massachusetts, Metropolitan Area. Transportation Research Record, (2174), 138-147. https://doi.org/10.3141/2174-18

Dubin, R. A. (1998). Predicting House Prices Using Multiple Listings Data. Journal of Real Estate Finance and Economics, 17(1), 35-59. https://doi.org/10.1023/A:1007751112669

Fan, G. Z., Ong, S. E., \& Koh, H. C. (2006). Determinants of house price: A decision tree approach. Urban Studies, 43(12), 23012316. https://doi.org/10.1080/00420980600990928

Freeman, A. M. (1979). Hedonic Prices, Property Values and Measuring Environmental Benefits: A Survey of the Issues. The Scandinavian Journal of Economics, 81(2), 154. https:// doi.org/10.2307/3439957

Gelain, P., \& Lansing, K. J. (2014). House prices , expectations , and time-varying fundamentals. Journal of Empirical Finance, 29(1), 3-25.

Hansen, L. P., \& Cochrane, J. H. (1992). Asset Explorations Pricing Macroeconomics for. In NBER Macroeconomics Annual 1992.

Harrison, D., \& Rubinfeld, D. L. (1978). Hedonic housing prices and the demand for clean air. Journal of Environmental Economics and Management, 5(1), 81-102. https://doi.org/10.1016/00950696(78)90006-2

Hussain, T., Abbas, J., Wei, Z., \& Nurunnabi, M. (2019). The effect of sustainable urban planning and slum disamenity on the value of neighboring residential property: Application of the hedonic pricing model in rent price appraisal. Sustainability, 11(4), 1144. https://doi.org/10.3390/su11041144

IBEF. (2020). Indian real estate industry report. Retrieved June 6, 2020, from IBEF website: https://www.ibef.org/industry/realestate-india.aspx

Kim, K., \& Park, J. (2005). Segmentation of the housing market and its determinants: Seoul and its neighbouring new towns in Korea. Australian Geographer, 36(2), 221-232. https://doi. org/10.1080/00049180500150019

Kok, S. H., Ismail, N. W., \& Lee, C. (2018). The sources of house price changes in Malaysia. International Journal of Housing Markets and Analysis, 11(2), 335-355. https://doi.org/10.1108/ IJHMA-04-2017-0039

Kuşan, H., Aytekin, O., \& Özdemir, I. (2010). The use of fuzzy logic in predicting house selling price. Expert Systems with Applications, 37(3), 1808-1813. https://doi.org/10.1016/j. eswa.2009.07.031
Li, W., Joh, K., Lee, C., Kim, J. H., Park, H., \& Woo, A. (2015). Assessing Benefits of Neighborhood Walkability to SingleFamily Property Values: A Spatial Hedonic Study in Austin, Texas. Journal of Planning Education and Research, 35(4), 471-488. https://doi.org/10.1177/0739456X15591055

Lisi, G. (2019). Property valuation: the hedonic pricing model - location and housing submarkets. Journal of Property Investment and Finance, 37, 589-596. https://doi.org/10.1108/ JPIF-07-2019-0093

Liu, X. (2013). Spatial and Temporal Dependence in House Price Prediction. Journal of Real Estate Finance and Economics, 47(2), 341-369. https://doi.org/10.1007/s11146-011-9359-3

Nguyen, H. C., \& Do, D. T. (2020). Factors Influencing the Perception of the Selling Price of Luxury Apartments. 7(5), 185-194. https://doi.org/10.13106/jafeb.2020.vol7.no5.185

Nguyen, J. (2016). 4 Key Factors That Drive The Real Estate Market. Investopedia.

Nguyen, M. L. T., Bui, T. N., \& Nguyen, T. Q. (2019). Relationships between real estate markets and economic growth in Vietnam. Journal of Asian Finance, Economics and Business, 6(1), 121128. https://doi.org/10.13106/jafeb.2019.vol6.no1.121

Oladunni, T., \& Sharma, S. (2017). Hedonic Housing Theory - A Machine Learning Investigation. 2016 15th IEEE International Conference on Machine Learning and Applications (ICMLA), 522-527. https://doi.org/10.1109/icmla.2016.0092

Oladunni, T., Sharma, S., \& Tiwang, R. (2017). A spatiotemporal hedonic house regression model. Proceedings - 16th IEEE International Conference on Machine Learning and Applications, ICMLA 2017, 2017-Decem, 607-612. https://doi. org/10.1109/ICMLA.2017.00-94

Pace, R. K., \& Zhu, S. (2017). Implicit Hedonic Pricing Using Mortgage Payment Information. Journal of Real Estate Finance and Economics, 54(3), 387-402. https://doi.org/10.1007/ s11146-016-9578-8

Pagourtzi, E., Assimakopoulos, V., Hatzichristos, T., \& French, N. (2003). Real estate appraisal: A review of valuation methods. Journal of Property Investment \& Finance, 21, 383-401. https://doi.org/10.1108/14635780310483656

Palmquist, R. B. (1980). Alternative Techniques for Developing Real Estate Price Indexes. The Review of Economics and Statistics, 62(3), 442-448.

Phuoc, L. T. (2018). Jensen's alpha estimation models in capital asset pricing model. Journal of Asian Finance, Economics and Business, 5(3), 19-29. https://doi.org/10.13106/jafeb.2018. vol5.no3.19

Prost, L., Makowski, D., \& Jeuffroy, M. H. (2008). Comparison of stepwise selection and Bayesian model averaging for yield gap analysis. Ecological Modelling, 219(1-2), 66-76. https://doi. org/10.1016/j.ecolmodel.2008.07.026

Randeniya, T., Ranasinghe, G., \& Amarawickrama, S. (2017). A model to Estimate the Implicit Values of Housing Attributes by 
Applying the Hedonic Pricing Method. International Journal of Built Environment and Sustainability, 4(2), 113-120. https:// doi.org/10.11113/ijbes.v4.n2.182

Ready, R. C., \& Abdalla, C. W. (2005). The amenity and disamenity impacts of agriculture: Estimates from a hedonic pricing model. American Journal of Agricultural Economics, 87(2), 314-326. https://doi.org/10.1111/j.1467-8276.2005.00724.x

Research and Markets. (2015). Indian Affordable Housing Market Analysis - The Changing Paradigm. Retrieved June 6, 2020, from https://www.researchandmarkets.com/research/8dw756/ indian_affordable

SELIM, S. (2008). Determinants of House Prices in Turkey : A Hedonic Regression Model. Doğuş Üniversitesi Dergisi, 1(9), 65-76. https://doi.org/10.31671/dogus.2019.223

Sirmans, G. S., Macpherson, D. A., \& Zietz, E. N. (2005). The composition of hedonic pricing models. Journal of Real Estate Literature, 13, 3-43.

Stadelmann, D. (2010). Which factors capitalize into house prices? A Bayesian averaging approach. Journal of Housing Economics, 19(3), 180-204. https://doi.org/10.1016/j.jhe.2010.07.002

Sunak, Y., \& Madlener, R. (2017). The impact of wind farms on property values: A locally weighted hedonic pricing model. Papers in Regional Science, 96(2), 423-444. https://doi. org/10.1111/pirs.12197

Sunding, D. L., \& Swoboda, A. M. (2010). Hedonic analysis with locally weighted regression: An application to the shadow cost of housing regulation in Southern California. Regional
Science and Urban Economics, 40(6), 550-573. https://doi. org/10.1016/j.regsciurbeco.2010.07.002

Tu, Q., de Haan, J., \& Boelhouwer, P. (2017). The mismatch between conventional house price modeling and regulated markets: insights from The Netherlands. Journal of Housing and the Built Environment, 32(3), 599-619. https://doi.org/10.1007/ s10901-016-9529-y

Wang, P., \& Kim, J.-P. (2014). The Value of Reverse Mortgage Loans: Case Study of the Chinese Market. Journal of Asian Finance, Economics and Business, 1(4), 5-13. https://doi. org/10.13106/jafeb.2014.vol1.no4.5.

Yoo, J., \& Ready, R. (2016). The impact of agricultural conservation easement on nearby house prices: Incorporating spatial autocorrelation and spatial heterogeneity. Journal of Forest Economics, 25(1), 78-93. https://doi.org/10.1016/j. jfe.2016.09.001

Yuan, F., Wei, Y. D., \& Wu, J. (2020). Amenity effects of urban facilities on housing prices in China: Accessibility, scarcity, and urban spaces. Cities, 96(April 2018), 102433. https://doi. org/10.1016/j.cities.2019.102433

Zainora Asmawi, M., Mohit, M. A., Noor, N. M., Abdullah, A., \& Paiman, T. (2018). Factor analysis on hedonic pricing model on open space affecting the housing price in melaka and seremban. Planning Malaysia, 16(2), 119-130. https://doi.org/10.21837/ pmjournal.v16.i6.467 